\title{
Estimating Efficiency In The Foreign Operations Of The USA Legal Services Industry
}

\author{
Harri Ramcharran, (E-mail: ramchar@uakron.edu), University of Akron
}

\begin{abstract}
This study analyzes the efficiency, resulting from overseas expansion, of the USA legal services industry. Expansion of trade in services has resulted in an increasing number of: (i) lawyers employed abroad, and (ii) countries with foreign offices. The results, derived from a production function methodology with cross-sectional data on large law firms, indicate that: (i) the number of lawyers employed abroad is optimal in terms of generating positive contribution to the production of legal services, and (ii) the foreign countries targeted by law firms for operations also yield positive contribution to revenue. In response to globalization and competition, the industry, using the FDI mode of entry, has exploited location advantage abroad in allocating lawyers and offices efficiently to benefit from the global integration of the industry.
\end{abstract}

\section{Introduction}

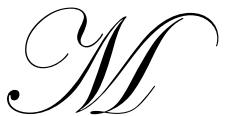

uch of the early literature on the multi-national enterprise (MNE) focuses mainly on manufacturing firms; recent studies, including Boddewyn, et al (1986), Dunning (1989), Buckley, et al (1992) and Nachum (2002), however, indicate a growing emphasis on services firms with foreign operations. Several factors contribute to this shift: (i) recently revised international trade agreements, for example, the General Agreement on Trade in Services (GATS), that differentiate trade in goods from trade in services (Stern and Hoekman, 1987), and call for the elimination of discriminatory practices in trade and services, ${ }^{1}$ (ii) the growing economic importance of the service sector of industrial countries, for example, in the US, services contribution to GDP increases from $11.6 \%$ in 1987 to $21.9 \%$ in $2000,{ }^{2}$ (iii) technological improvements that have reduced the economic distance (transportation costs and transaction costs that result from differences in culture and language) between trading partners (Hoekman and Sauve, 1994), and (iv) the growing significance of non-material assets (knowledgebased inputs) as creators or facilitators of wealth in the growth of industrialized countries (Dunning, 1998).

From an analytical perspective, Buckley, et al (1992, p. 44) aver that, "international service firms can be regarded as multinational enterprises and are thus open to scrutiny with in the ambit of the multinational enterprise." "3 Researchers, for example, Behrman (1972) and Dunning (1980), have categorized the MNE as (i) raw material seekers, (ii) market seekers, (iii) strategic asset seekers, and (iv) efficiency seekers. The allocative efficiency of the MNE has not been empirically investigated despite the documentation of economies of scale/scope as a primary motive for FDI. This neglect could result in the MNE realizing a sub optimal rate of return in a global competitive economy. Trade in services (law, insurance, accounting, engineering, banking, etc.), resulting from the geographic expansion of markets (because of liberalization of trade, investments and capital flows), constitutes a very dynamic component of the global economy. Researchers, including Nachum (2000) and Gray and Gray (1981), have analyzed the factors that determine the location advantages of professional services abroad; however, the efficiency derived from foreign location has not been examined.

The US legal services industry provides an interesting case-study for investigating the operational efficiency associated with the global integration of markets and the internationalization of services because of the following reasons: (i) rapid globalization of capital markets and cross-border business activities have spurred an 
increasing in demand for legal services, thus necessitating law firms to internationalize to meet this demand (Bohlhoff, 1995), (ii) the industry has contributed significantly to GDP, the growth rate in employment, and the surplus in the balance of trade in services, and (iii) the availability of recent data (American Lawyer, 1998) that document the following information: revenue generated per lawyer, the number of lawyers employed abroad, and the number of countries with offices. We apply a production function technique based on the microeconomic theory of optimal (necessary and satisfactory conditions) resource allocation to estimate the allocative efficiency of (i) the number of lawyers employed abroad, and (ii) the number of countries targeted for foreign operations. The data includes a cross section of 26 top US law firms (listed in the Appendix, Table 1A) that are currently engaged in cross-border trade of legal services. ${ }^{4}$

The results of this study have two important implications pertaining to the hypothesized motives for FDI. (1) If productivity (defined in terms of revenue generated) per lawyer employed abroad is positive and increasing, there is evidence of allocative efficiency consistent with the "efficiency-seeking" motive for FDI. (2) If productivity (in terms of revenue generated) from countries with law offices is positive and increasing, there is evidence of efficiency, consistent with the motive for exploiting location (geographic) advantage. This implication also suggests that U.S. law firms employ the optimal mode of entry (to deliver legal services) that overcomes country-specific regulatory restrictions.

From a theoretical perspective, Dunning's (1988) eclectic paradigm of the MNE provides a useful framework for analyzing the internationalization and efficiency of this industry. First, law firms possess ownership advantage of an intangible asset. Second, the provision of services is associated with buyers' uncertainty, (which is a significant cost), thus a cost minimizing strategy necessitates law firms to internalize the ownership advantage (Casson, 1982). Third, a maximum presence is necessary in a specific location to provide some categories of services; for demander/located services, such as legal, the closeness to the customers constitutes the location advantage. The mode of entry abroad is determined by two aspects of the characteristics of services: (i) legal services possess non-divisibility or transitory character, i.e. production and consumption occur simultaneously, and (ii) the provision of legal service involves producer/consumer interaction, thus the control over the delivery of services is achieved through the establishment of branches or subsidiaries abroad, consistent with the FDI mode of entry.

The contribution of this study is significant in light of the rapid growth in MNE activities that have generated much research interest. Specifically, it expands the empirical literature on the motives of FDI by investigating the "efficiency seeking" hypothesis. The focus on a service industry enhances the policy implications of the results given the growing concern about removing non-quantitative barriers to the internationalization of legal services under GATS. ${ }^{5}$ Recent studies of productivity in the US legal services industry, for example, Wang (2000), Cross (1998 and 1992), and Magee (1992) employ an aggregate approach to analyze the productive efficiency of lawyers in the U.S. law firms. The weakness of these studies is their failure to examine lawyers' productive efficiency in the overseas operations of law firms despite the growing importance of this sector of operations.

The rest of the paper is as follows: an overview of trade in services, the economic importance of the legal services industry, the relevant literature, methodology, results and conclusions.

\section{Trade In Services: An Overview}

The pre-Uruguay Rounds of GATT focused primarily on trade in goods; services were considered inputs (intangibles or invisibles). The US proposal to GATT in 1982 was a framework for trade in services (TIS), it delineates the differences between the economic nature of goods and of services, emphasizes the growing importance of services to the world economy, and argues for a more liberal policy in TIS. Although the distinction between goods and services cannot be viewed as a simple black and white categorization, traditional economists, for example, Bhagwati, (1994), attempt to define services largely by contrast with goods. The contrasts emphasize (i) the non-storability, (ii) the intangibility or invisibility, and (iii) the non-durability or transitory character of services. It is possible to find exceptions to each of these definitions. The implications of the nature of services are crucial for 
the mode of supply of services (Hoekman, 1996). Three modes of TIS are identified: (i) pure cross border, which corresponds to traditional trade in goods (TIG) where producers, located in one country export the services to consumers, located in another country; (ii) TIS based on the international mobility of factors; one of the two agents travel to the other country to produce (mobile producer), or consume the service (mobile user); and (iii) TIS based on factor establishment; the provider establishes a permanent subsidiary in the importing country in order to produce and sell the services, similar to TIG, associated with FDI and labor movement. ${ }^{6}$

The US proposal to GATT also included theoretical arguments for recommending a free trade policy for TIS. Deardorff (1985), Jones (1985), and Hindley and Smith (1984) provide justification based on the principle of comparative advantage. However, researchers including Gray and Gray (1981), Casson (1982), Boddewyn, et al (1986), Dunning (1989), Buckley, et al (1992), and Nachum (2002), are supportive of the eclectic theory of Dunning (1985) in providing a better explanation of the motive and performance of the international service firms. Dunning (1998) delineates the applicability and advantages of the OIL paradigm with the emergence of intellectual capital as the key wealth-creating asset in industrial countries.

Location advantage is crucial for the performance of the multinational service firm. Location theory assumes that firms locate their production where immobile inputs are cheapest and the average production costs can consequently be minimized. For demander-located or location-bound services (such as legal services) where interaction between supply and demand is essential, location also depends on the closeness to customers and the need to adapt to customers' requirements. Two other factors affect location: (i) economic distance, defined as the sum of the costs arising from geographic distance (transport) and the transaction costs of various kinds (including differences in culture, language, etc.) and, (ii) regulatory barriers to the supply of services across frontiers.

Despite GATS calling for the elimination of restrictions in TIS, OECD (1996) identify many key obstacles (non-quantitative barriers) to the internationalization of legal services; these include the lack of adequate access to local markets, restrictions concerning the establishment of firms, the recognition of the qualification of foreign professionals, and nationality requirements. Cone (1995), Godfrey (1995), Klein (1996) and Ramcharran (1999) provide extensive analyses of the regulatory and institutional barriers to the expansion of US law firms overseas.

\section{Economic Importance Of The Us Legal Services Industry}

For the past decade, the US policy makers have paid increasing attention to the international competitiveness of the economy particularly the growing impact of the deficit on merchandise trade. Blaine (1996) contends that the causes of persistent trade imbalance could be attributed to (a) a declining manufacturing base and (b) a shift of the economy towards services. In 1980 the services sector contribution to GDP (nominal) was $16.1 \%$; it increased to $21.9 \%$ in $2000{ }^{7}$ Legal services contribution to GDP rose from $\$ 25$ billion in 1980 to $\$ 133.5$ billion in 2000; over the last five years, this contribution averages to about $1.4 \%$ of GDP. ${ }^{8}$ Recent data reveal an increasing merchandise trade deficit from 1985 to 2001 and an increasing trade surplus in services over this period (see Table 3A). Exports in legal services, although a small portion of total services, grew rapidly from $\$ 97$ million in 1986 to $\$ 3,214$ million in 2000, while the net balance in trade in legal services grew from the surplus of $\$ 57$ million in 1986 to $\$ 2,375$ million in 2001 (see Table 4A).

Total employment (full time and part time) in the legal services industry was 1,083,000 in $2001 .{ }^{9}$ In addition to the legal services industry, lawyers are employed in other economic sectors (banking, manufacturing, etc.), thus, a focus just on the legal service sector may underestimate the positive impact of the legal profession on the economy. Competition in the legal services industry over the past decade has forced law firms to identify profitable niche markets at home and abroad. The foreign operations of some of the largest U.S. law firms have increased faster than their domestic operations because of the rapid expansion of global markets and their profit opportunities, (Barret, 1997 and Rice, 1997). The foreign operations of US law firms are concentrated in countries with significant US FDI and banking (see Appendix, Table 2A). 


\section{Relevant Literature}

Early studies of the determinants of FDI, for example, Aggarwal (1980), Cantwell (1982) and the United Nations (1992), focus on manufacturing firms. The methodology incorporates the least cost location theory with investment theory. Behrman (1972) identifies four types of MNE: resource seekers, markets seekers, efficiency seekers, and strategic asset seekers. Resource seekers are prompted to invest abroad to acquire or get access to specific resources at a lower cost that could not be obtained in their home countries; these MNE are driven by the cost-minimization motive. The goal of the efficiency seeking MNE is to take advantage of different factor endowments for benefits related to economies of scale and scope, and risk diversification. Market seekers aim at having access to new customers.

Gray and Gray (1981) articulate the structure of international banking (services) within the framework of the multi-national corporation. Based on this paradigm, Goldberg and Johnson (1990) analyze the determinants of US banking activity banking abroad, while Grosse and Goldberg (1991) foreign banking activity in the USA. The increasing economic importance of services in the world economy, generated by globalization and trade liberalization policies under GATS, has stimulated new research interest. Buckley, et. al (1992) aver that international service firms can be regarded as MNE and be analyzed within similar methodological framework. Nachum (2002) analyzes factors that determined the location advantages of professional services firms, however, like previous investigators; the efficiency derived from foreign location has not been estimated.

Regarding productivity in the legal services industry, Wang (2000) estimate a stochastic frontier production function using 1994 data on a sample of 163 large U.S. law firms; he finds that: (i) the number of lawyers has a statistically significant positive impact on the production of legal services, and (ii) $17.8 \%$ inefficiency due to either excessive input usage or mismanagement. The weakness of this study is the failure to differentiate between the domestic and the foreign components of efficiency. Other studies, for example, Magee (1992) and Cross $(1992,1998)$, focus on the economic contribution of lawyers in response to the controversial issue of the negative impact on the U.S. economy caused by an excess of lawyers and too much litigation. Magee (1992) employs a macro-economic approach using economic and socio-political data. Cross, (1998) modifies Magee's econometric approach by using, additional independent variables and more robust statistical procedures. The results indicate no significant negative association between the number of lawyers and economic growth. Interestingly, Cross (1998, p 480) contends that, "given the growing importance of international trade, United States lawyers may have an effect on foreign economies as well as our own". This assertion has never been investigated nor tested.

The results of this research, focusing on the "efficiency seeking" hypothesis, have important policy implications regarding global human resource allocation and geographical diversification.

\section{Methodology}

A production function model with the firm's revenue, as the measure of output (dependent variable), similar to Wang (2000), is estimated. The measure of output in service industries is difficult to estimate (Griliches, 1992), especially for law firms that provide multiple services to a variety of clients. The independent variable is the number of lawyers employed since the production of legal services is highly labor intensive. It would have been appropriate to use the number of billable hours, but the unavailability of systematic data makes this impossible. Theoretically, we should also use a variable indicating capital input, measured by expenses for office furniture, equipment, and rent; however, data on these expenses are not available. Wang (2000) contends that large law firms, in making production decisions, are primarily concerned with labor inputs and only secondarily about capital (nonhuman) inputs. The other independent variables used are: (a) the number of lawyers employed abroad (OUT), and (b) the number of countries where each firm has law offices (COUN). These data are presented in Table 1A.

First, we analyze the aggregate performance of law firms, postulating that output (REV) of a law firm is the function of the total number of lawyers (LAW) employed. We estimate the following equation:

$$
\operatorname{REV}=\mathrm{a}_{0}+\mathrm{a}_{1} \text { LAW } \quad \text { Eq. } 1
$$


The coefficient $\mathrm{a}_{1}$ in Eq. 1 measures the output generated by each additional lawyer commonly referred to as the marginal productivity of labor/lawyer (MPL). If $a_{1}>0$, then each additional lawyer contributes positively to the firm's output (revenue). Economic theory postulates that under the output maximization goal, additional resources could be employed as long as marginal productivity is positive (MPL $>0$ ) ${ }^{10}$. Excessive employment is associated with negative marginal productivity (MPL $<0$ ). We further examine the dynamic aspect of output generation using the quadratic specification of Eq. 1 by including another independent variable, $\mathrm{LAW}^{2}$ (the squared value of LAW).

$$
\mathrm{REV}=\mathrm{a}_{0}+\mathrm{a}_{1} \mathrm{LAW}+\mathrm{a}_{2} \mathrm{LAW}^{2}
$$

The coefficient of $a_{1}$ is the MPL, and of $a_{2}$ the rate of change in MPL. If $a_{2}$ is negative (positive) and significant, it suggests that the MPL increases at a decreasing (increasing) rate. Optimization conditions are satisfied with $\mathrm{a}_{1}>0$, and $\mathrm{a}_{2}<0 .{ }^{11}$

Second, we focus on the international dimension of revenue generation by law firms. We postulate that output is associated with the number of lawyers each firm employs abroad (LOUT) and the number of countries where each firm has foreign offices (COUN). The relationship is specified as:

$$
\begin{aligned}
& \text { REV }=a_{0}+a_{1} \text { LOUT }+a_{2} \text { COUN } \\
& a_{1}>0, \quad a_{2}>0
\end{aligned}
$$

A priori, one would expect a high correlation between LOUT and COUN; if this is detected then the bivarite estimation (specified as Eq. 4 and Eq. 5) will be done:

$$
\begin{aligned}
& \mathrm{REV}=\mathrm{a}_{0}+\mathrm{a}_{1} \text { LOUT } \\
& \text { Eq. } 4 \\
& \mathrm{REV}=\mathrm{a}_{0}+\mathrm{a}_{1} \text { COUN } \\
& \text { Eq. } 5
\end{aligned}
$$

Finally, we examine the sensitivity of the results to variation in the definition of output by using output/revenue per lawyer (RVPL) as the dependent variable. The dynamic aspect of international allocation is assessed by using two sets of independent variables: (a) LOUT and LOUT $^{2}$ (the squared value of LOUT) and (b) COUN and $\operatorname{COUN}^{2}$ (the squared value of COUN).

$$
\begin{aligned}
& \text { RVPL }=a_{0}+a_{1} \text { LOUT }+a_{2} \text { LOUT }^{2} \\
& \mathrm{RVPL}=\mathrm{b}_{0}+\mathrm{b}_{1} \mathrm{COUN}+\mathrm{b}_{2} \text { COUN }^{2}
\end{aligned}
$$

The sign of $a_{1}$ indicates whether the output/revenue contribution from lawyers employed abroad (LOUT) is positive or negative, and the sign of $a_{2}$ the rate of (increasing or decreasing) the contribution. Similarly, the sign of $b_{1}$ indicates whether the output/revenue contribution from COUN is positive or negative, and the sign of $b_{2}$ the rate of change (increasing or decreasing) in the contribution. Like Eq. 2, if $\mathrm{a}_{1}>0, \mathrm{a}_{2}<0$, and $\mathrm{b}_{1}>0, \mathrm{~b}_{2}<0$, then the necessary and sufficient conditions for the optimal use of LOUT and COUN are satisfied.

\section{Emperical Results}

The results of the regression estimates are presented in Table 1. The results of Eq. 1 indicate that the estimate of the slope coefficient (315.63) is positive and significant at the 1\% level. This coefficient is the estimate of MPL, the output generated by each lawyer. It indicates that additional lawyers could be hired since economic theory postulates that under the revenue maximization strategy a resource is efficiently employed as long as MPL $>0$. Based on the results, the argument of excessive of lawyers in the United States is disproved. 
Table 1 Regression Results (t values in parentheses)

\begin{tabular}{|c|c|c|}
\hline Eq. 1: & $\begin{array}{c}\mathrm{REV}=92021.2+315.63 \mathrm{LAW} \\
(5.39)^{* * *}\end{array}$ & $\mathrm{R}^{2}=0.59$ \\
\hline Eq. 2: & $\begin{array}{r}\text { REV }=-303735.8+1081.96 \mathrm{LAW}-0.279 \mathrm{LAW}^{2} \\
(4.18)^{* * *} \quad(-3.018)^{* * *}\end{array}$ & $\mathrm{R}^{2}=0.71$ \\
\hline Eq. 3: & $\begin{array}{c}\text { REV }=214564.9-6831.024 \text { LOUT }+279226.54 \text { COUN } \\
(-1.68)\end{array}$ & $\mathrm{R}^{2}=0.42$ \\
\hline Eq. 4: & $\begin{array}{c}\text { REV }=295041.0+3722.037 \text { LOUT } \\
(2.3)^{*}\end{array}$ & $\mathrm{R}^{2}=0.20$ \\
\hline Eq. $5:$ & $\begin{array}{c}\mathrm{REV}=250008.4+12013.04 \mathrm{COUN} \\
(3.3)^{* * *}\end{array}$ & $\mathrm{R}^{2}=0.34$ \\
\hline Eq. 6: & $\begin{array}{r}\text { RVPL }=441.6+8.773 \text { LOUT }-1.2729 \text { LOUT }^{2} \\
(2.35)^{* *} \quad(-2.55)^{* *}\end{array}$ & $\mathrm{R}^{2}=0.24$ \\
\hline Eq. 7: & $\begin{array}{r}\mathrm{RVPL}=381.22+25.87 \mathrm{COUN}-0.794 \mathrm{COUN}^{2} \\
(2.41)^{* *}\end{array}$ & $\mathrm{R}^{2}=0.26$ \\
\hline$* * *$ & $\begin{array}{l}\text { ignificance and the } 5 \% \text { level } \\
\text { ignificance and the } 1 \% \text { level }\end{array}$ & \\
\hline
\end{tabular}

In Eq. 2, the coefficients of LAW (1081.96) and of $\mathrm{LAW}^{2}(-0.279)$ have the expected signs and are both significant at the $1 \%$ level. Besides positive MPL, the results suggest that output contribution increases at a decreasing rate, consistent with optimization conditions. From a productivity perspective, law firms are allocating the numbers of lawyers efficiently. Eq. 2 , with $\mathrm{R}^{2}=0.71$.

The impact of foreign operations, as indicated by LOUT and COUN, on the firm's output/revenue is given by the estimates of Eq. 3. Only the coefficient of COUN is significant at the 5\% level with the correct sign, indicating that there is a positive association with revenue and the number of countries where lawyers are employed. However, the correlation matrix shows a very high correlation of 0.98 between LOUT and COUN. To eliminate any bias in the coefficient estimates because of the collinearity, we estimate the impact of each variable using separate equations. ${ }^{12}$ The results, shown in Eq. 4 and Eq. 5, indicate that both variables separately have a positive and significant impact on REV.

The results of Eq. 6 and Eq. 7, based on a variation in the definition of output (the dependent variable is revenue per lawyer (RVPL) instead of REV) show that the coefficient of LOUT is positive and of LOUT ${ }^{2}$ negative; both are significant and indicate that each lawyer employed abroad contributes positively to output and at a decreasing rate, consistent with the revenue maximizing conditions. Additionally, the coefficient of COUN is positive and of COUN ${ }^{2}$ negative, both significant and suggest that the countries where the law firms are located are contributing efficiently to output. These findings are supportive of management understanding of the country specific problems and of the implementation of appropriate strategies to take advantage of profit opportunities abroad by allocating lawyers efficiently.

The results of positive contribution to output by the total numbers of lawyers employed are similar to Wang (2000) who also finds about $17.8 \%$ inefficiency (due to either excessive input usage or mismanagement). The only indicator of inefficiency, if at all, that could be inferred from our results is based on the output elasticity of a lawyer, 0.921 obtained from the logarithmic estimation of Eq. 1. The value of this coefficient suggests that $1 \%$ increase in the number of lawyers contribute $0.92 \%$ increase in revenue; this should be considered very minimal regarding inefficiency. 


\section{Conclusions}

The efficiency of the multinational service enterprise, from a factor allocation perspective, has not been fully examined by researchers. This study, applying the economic theory of optimal resource allocation, analyzes the efficiency of lawyers in the U.S. legal service industry within the framework of Dunning's eclectic paradigm. The empirical results indicate that from the perspective of: (a) global operation, the legal service industry has identified profitable markets (countries) where the number of lawyers allocated is optimal, and (b) total number of lawyers employed, revenue contribution per lawyer is a positive and significant. The pattern of productivity, indicative of efficiency in human resources allocation as well as location choice, must be considered satisfactory, given the legal, cultural and institutional barriers U.S. law firms confront abroad.

Global expansion of cross-border merger and acquisitions, investment banking activities, international bankruptcy and arbitration etc, will increase the demand for legal services. Additionally, the mode of delivering legal services abroad could significantly change in the future as technological improvements reduce the geographic, economic and psychic costs. However, challenges to globalization, posed by, inter alia, political and economic risks, could also affect the performance of this industry. As the results of this study are based on data published for the first time, there is opportunity for future study if similar data are published continuously.

\section{Notes}

1. The GATS resulted from the Uruguay Round of the General Agreement on Tariffs and Trade (GATT) trade negotiations (1986-93).

2. "GDP by Industry 1998-2000", Survey of Current Business (Nov., 2001), "GDP by Industry 1991-1992" (October 1994) and "Improved Estimates of GDP by Industry for 1947-1998" Survey of Current Business (June, 2000).

3. Boddewyn et al (1986) provide additional arguments why international service firms satisfy the characteristic of the MNE

4. American Lawyer (1998) lists the top 50 global law firms (in terms of gross revenue generated); of these 7 are from the U.K. and the rests from the U.S.A. We chose only the law firms from the U.S.A. with foreign operations, i.e, with offices and lawyers abroad.

5. There is also the growing concern about reforming the nation's civil justice system on issues such as high attorney fees (Quale, 1992), rapid increase in billable hours by lawyers (Bogus, 1996), and high litigation costs (Wood, 1998).

6. Stern and Hoekman (1987) identify four types of services: (i) separate services (no-movement of supplier and customer), (ii) demander-located services (movement of supplier alone), (iii) provider located services (movement of customer only), and (iv) foot-lose or non-located services (movement of both supplier and customer). Most legal services are essentially demander-located, and thus have to be produced abroad as such the FDI mode of entry is primary. This is evidenced by the large number of foreign offices for US firms.

7. "GDP by Industry 1998-2000", Survey of Current Business, (US Department of Commerce, Nov. 2001).

8. Ibid.

9. $\quad$ Statistical Abstract of the United States, (US Department of Commerce, 2002).

10. See Hirschey and Pappas (1993). The conventional short run total output (Q) curve is S shaped, suggesting that $Q$ first increases at an increasing rate, then increases at decreasing rate, reaches a maximum and finally decreases as the employment of the variable input (or resource employed) increases. Marginal product (MPL), which is the slope of the total product curve, increase when $\mathrm{Q}$ increases, equals zero when $\mathrm{Q}$ is at maximum, and is negative when $\mathrm{Q}$ decreases. Optimal resource allocation corresponds to MPL $=0$. If MPL is positive and increases at decreasing rate then the allocation of resources approaches optimality.

11. See also, W. Shughart, W. Chappell and R. Cottle, Modern Managerial Economics (1994).

12. A commonly used rule of thumb is that a correlation coefficient between two explanatory variables greater than 0.8 or 0.9 indicates a strong linear association and a potentially harmful collinear relationship. See C. Hill, W. Griffiths and G. Judge, Undergraduate Econometrics (1997). 


\section{APPENDIX}

Table 1A: Relevant Data on US Law Firms

Law Firm
1. Baker \& McKenzie
2. Jones, Day, Ravis
3. Skadden, Arps, Slate
4. Morgan, Lewis \& Bockius
5. Latham and Watkins
6. Sidley \& Austin
7. White \& Case
8. McDermott, Will \& Emery
9. Maier, Brown \& Plat
10. LeBoeuf, Lamb, Greene
11. Akin, Gump, Strauss
12. Foley \& Lardner
13. Gibson, Dunn, Crutcher
14. Wiel, Gotshal \& Manges
15. Morison \& Forester
16. O'Melveny \& Mayers
17. Fulbright \& Jaworsky
18. Shearman \& Sterling
19. Cleary, Gottlieb, Stine
20. Hunton \& Williams
21. Hogan \& Hartson
22. Pilsbury, Madison \& Sutro
23. Vinson \& Elkins
24. Kirkland \& Ellis
25. Paul, Hastings \& Walker
26. Baker \& Botts

\begin{tabular}{|c|c|c|c|}
\hline 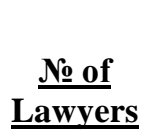 & $\frac{\underline{\text { No of }}}{\text { Lawyers }}$ & $\frac{\text { Countries }}{\text { with }}$ & 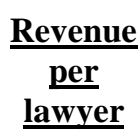 \\
\hline 2300 & $80 \%$ & 35 & $\$ 335,000$ \\
\hline 1191 & $10 \%$ & 10 & $\$ 430,000$ \\
\hline 1125 & $9 \%$ & 11 & $\$ 770,000$ \\
\hline 901 & $6 \%$ & 6 & $\$ 430,000$ \\
\hline 811 & $5 \%$ & 4 & $\$ 580,000$ \\
\hline 811 & $5 \%$ & 4 & $\$ 510,000$ \\
\hline 778 & $46 \%$ & 23 & $\$ 485,000$ \\
\hline 762 & $2 \%$ & 3 & $\$ 510,000$ \\
\hline 752 & $5 \%$ & 8 & $\$ 495,000$ \\
\hline 736 & $13 \%$ & 9 & $\$ 395,000$ \\
\hline 628 & $4 \%$ & 4 & $\$ 385,000$ \\
\hline 681 & $0 \%$ & 1 & $\$ 380,000$ \\
\hline 675 & $2 \%$ & 4 & $\$ 590,000$ \\
\hline 661 & $14 \%$ & 6 & $\$ 590,000$ \\
\hline 653 & $5 \%$ & 6 & $\$ 440,000$ \\
\hline 645 & $4 \%$ & 4 & $\$ 505,000$ \\
\hline 621 & $1 \%$ & 3 & $\$ 440,000$ \\
\hline 605 & $25 \%$ & 9 & $\$ 630,000$ \\
\hline 572 & $33 \%$ & 8 & $\$ 735,000$ \\
\hline 568 & $11 \%$ & 5 & $\$ 420,000$ \\
\hline 564 & $11 \%$ & 6 & $\$ 400,000$ \\
\hline 552 & $1 \%$ & 3 & $\$ 430,000$ \\
\hline 554 & $4 \%$ & 4 & $\$ 500,000$ \\
\hline 546 & $1 \%$ & 2 & $\$ 525,000$ \\
\hline 529 & $1 \%$ & 3 & $\$ 460,000$ \\
\hline 496 & $2 \%$ & 3 & $\$ 495,000$ \\
\hline
\end{tabular}

Source: The American Lawyer, November 1998

Table 2A: Main Foreign Location of US Law Firms

\begin{tabular}{cc} 
City & № of Attorneys \\
\cline { 2 - 2 } London & 496 \\
Hong Kong & 354 \\
Brussels & 215 \\
Tokyo & 100 \\
Parris & 360
\end{tabular}

Source: The National Law Journal, August 12, 1996 
Table 3A: US Trade Balances (\$Mil) 1985-2001

\begin{tabular}{lccc} 
Year & $\frac{\text { Balance on }}{\text { Goods }}$ & $\frac{\text { Balance on }}{\text { Services }}$ & Balance on Current \\
\hline 1985 & $-122,173$ & & $\underline{\text { Account }}$ \\
1986 & $-145,081$ & 294 & $-118,115$ \\
1987 & $-159,557$ & 6,543 & $-147,177$ \\
1988 & $-126,959$ & 7,874 & $-160,655$ \\
1989 & $-117,749$ & 12,393 & $-121,153$ \\
1990 & $-111,034$ & 24,607 & $-99,486$ \\
1991 & $-76,937$ & 31,073 & $-78,965$ \\
1992 & $-96,897$ & 45,802 & 37,447 \\
1993 & $-132,451$ & 60,440 & $-48,515$ \\
1994 & $-165,831$ & 63,660 & $-82,523$ \\
1995 & $-174,170$ & 69,153 & $-118,244$ \\
1996 & $-191,000$ & 77,782 & $-105,823$ \\
1997 & $-198,119$ & 89,157 & $-117,821$ \\
1998 & $-246,696$ & 90,354 & $-128,372$ \\
1999 & $-346,022$ & 79,763 & $-203,827$ \\
2000 & $-452,423$ & 83,785 & $-292,856$ \\
2001 & $-427,165$ & 73,742 & $-401,340$ \\
& & 68,875 & $-393,371$
\end{tabular}

Source: US International Transactions, Survey of Current Business, July 2002, Table 1.

Table 4A: US Cross-border Trade in Legal Services (\$Mil) 1986-2000

$\begin{array}{cccc}\frac{\text { Year }}{1986} & \text { Exports } & \frac{\text { Imports }}{40} & \underline{\text { Balance }} \\ 1987 & 97 & 56 & 57 \\ 1988 & 147 & 98 & 91 \\ 1989 & 272 & 81 & 174 \\ 1990 & 397 & 111 & 316 \\ 1991 & 451 & 244 & 340 \\ 1992 & 1,309 & 311 & 1,065 \\ 1993 & 1,358 & 321 & 1,047 \\ 1994 & 1,442 & 383 & 1,121 \\ 1995 & 1,617 & 469 & 1,234 \\ 1996 & 1,667 & 615 & 1,198 \\ 1997 & 1,943 & 539 & 1,328 \\ 1998 & 2,223 & 655 & 1,684 \\ 1999 & 2,406 & 736 & 1,751 \\ 2000 & 2,463 & 839 & 1,727 \\ & 3,214 & & 2,375\end{array}$

Source: Cross-border Trade in Services, 1986-2000, Survey of Current Business, October 2001, Table 1 


\section{References}

1. Aggarwal, J.P, (1980). Determinants of Foreign Direct Investment Welt. Archiv, Heft 4. 739-773.

2. _ _ _ _ _ _ _ 30.

3. Barret, P. M. (1997), "Law Firms See Profits Reach All-Time High", New York Times, July 1, B8

4. Behrman, J. N. (1972), "The Role of International Companies in Latin America: Autos and Petroleum, Lexington Books, Lexington MA

5. Bhagwati, J.N. (1984), "Splintering and Disembodiment of Services and Developing Nations," The World Economy, 133-144.

6. Blaine, M. (1996), "Trade, FDI, and the Dollar: Explaining the U.S. Trade Deficits", Sloan Management Review (Fall), 81-98.

7. Boddewyn, G.G., M.B. Halbrick, and A.C. Perry. (1986), "Service Multinationals: Conceptualization Measurement and Theory," Journal of International Business Studies, 16, 41-57

8. Bogus, C. T. (1996), "The Death of An Honorable Profession” Indiana Law Journal, 71, 911-950

9. Bohlhoff, K. (1995), “How do Law Firms Go Global?”, International Business Lawyer, (Dec.) 534-537

10. Buckley, P. J, C.L. Pass, and K. Prescott. (1992), "The Internationalization of Service Firms: A Comparison with the Manufacturing Sector," Scandinavian International Business Review, 1, 39-57

11. Cantwell, J. (1982). International production and international trade in D. Greenway and L.A. Winters (Eds.), Surveys in International Trade, Blackwell Publishers.

12. Casson, M.C. (1982), "Transaction Costs and the Theory of the Multinational Enterprise" in New Theories of the Multinational Enterprise, edited by A.M. Rugman, St. Martines' Press, 24-43

13. Cone, T. (1995), "General Agreement on Trade in Services", International Business Lawyer, (Dec.) 529531

14. Cross, F. B. (1992), "The First Thing We Do, Let's Kill All the Economists: An Empirical Evaluation of the Effect of Lawyers on the United States Economy and Political System", Texas Law Review, (Feb.), 645-684

15. Cross, F. B. (1998), "Lawyers, The Economy and Society", American Business Law Journal, 35, (Summer), 477-514

16. Deardorff, A.V., (1985),"Comparative Advantages and International Trade in Services," in R. M. Stern, Trade and Investment in Services: Canada-US Perspective, University of Toronto Press.

17. Dunning, J.H. (1980), Toward an Eclectic Theory of International Production: Some Empirical Tests, Journal of International Business Studies, 11 (1), 9-13

18. Dunning, J.H. (1988), "The Eclectic Paradigm of International Production: A Restatement of Some Possible Extension," Journal of International Business Studies, 19 (1), 1-32

19. Dunning, J.H. (1989), "Multinational Enterprises and the Growth of Services: Some Conceptual and Theoretical Issues," Service Industries Journal, 19, 5-37

20. Dunning, J.H. (1998), "Location and the Multinational Enterprise: A Neglected Factor," Journal of International Business Studies, 29 (1), 45-66

21. $\quad$ Epp C. R. (1992), "Do Lawyers Impair Economic Growth?” Law \& Soc. Inquiry 17, 585-600

22. Godfrey, E. (1995), "The Globalization Debate”, International Business Lawyer, (Dec.) 507-509

23. Goldberg, L.G. and D. Johnson (1990), "The Determinants of US Banking Activity Abroad), Journal of International Money and Finance, 9, 123-37

24. Gray, J.M. and H.P. Gray (1981), "The Multinational Bank: A Financial MNC," Journal of Banking and Finance, 10, 33-63

25. Grosse, R. and L.G. Goldberg (1991), "Foreign Bank Activity in The United States: Analysis of Country of Origin", Journal of Banking and Finance, 15, 1093-1112

26. Griliches, Z. (1992), Output Measurement in the Service Sectors, NBER, The University of Chicago Press

27. Hill, C., W. Griffiths and G. Judge. (1997), Undergraduate Econometrics (J. Wiley \& Sons, Inc.)

28. Hindley, B. and Smith, A. (1984), "Comparative advantage in trade and services", The World Economy, pp. 369-390.

29. Hirschey, M. and J. L. Pappas. (1993), Managerial Economics (The Dryden Press) $7^{\text {th }}$ Edition 
30. Hoekman B. M. (1996), "Assessing the General Agreement in Trade in Services" in The Uruguay Round and the Developing Countries: eds W. Martin and L. Allan Winters (Cambridge University Press, New York), 84-124.

31. Hoekman B. M, and P. Sauve. (1994), Liberalizing Trade in Services, World Bank Discussion Papers \# 234.

32. International Trade and Professional Services, (1996), (OECD, Paris).

33. Jones, R.W. (1985), “ A comment on comparative advantages in international trade in services" in R.M Stern (Ed.) Trade and investment in services: Canada-US perspectives, University of Toronto Press for the Ontario Economic Council.

34. Klein, C. (1996), "Gold Rush Thin Stakes", The National Law Journal, (August 12).

35. Magee S. P. (1992), "The Optimum Number of Lawyers: A Reply to Epp”, Law \& Social Inquiry, 17, 667680

36. Nachum, L. (2000), "Economic Geography and the Location of TNCs: Financial and Professional Service FDI to the USA," Journal of International Business Studies, 31 (3), 367-387

37. Quayle, D. (1992), "Civil Justice Reform” American University Law Review, 41, 559-575

38. Ramcharran H. (1999), "Trade Liberalization in Services: An Analysis of The Obstacles and The Opportunities for Trade Expansion By U.S.A. Law Firms”, Multinational Business Review, 4, (Spring) 27 36

39. Rice, R. (1997), "Hotter Competition in Global Law Race" Financial Times (June) B8

40. Shughart, W., W. Chappell and R. L. Cottle. (1994), Modern Managerial Economics (South-Western Publishing Co.)

41. Stern, R. and B. Hoekman (1987), "Negotiation in Services", World Economy, 10, 39-60.

42. Survey of Current Business.( 2001), U.S Dept of Commerce, November.

43. The Determinants of Foreign Direct Investment: A survey of the Evidence, United Nations 1992.

44. The Global 50. (1998), The American Lawyer, November.

45. Wang, Weiren. (2000), "Evaluating the technical efficiency of large US law firms", Applied Economics, 32, 689-695

46. Wood, A. (1998), "Legal Costs Too High” Chemical Week, 160, 33-36 
$\underline{\text { Notes }}$ 